\title{
PENGARUH KOMPLEKSASI INKLUSI ATORVASTATIN DENGAN $\beta$-SIKLODEKSTRIN TERHADAP FORMULASI DAN EVALUASI FAST DISINTEGRATING TABLETS (FDT) ATORVASTATIN
}

\author{
THE INFLUENCE OF THE INCLUSION COMPLEXATION WITH \\ $\beta$-CYCLODEXTRYN ATORVASTATIN AGAINST \\ THE FORMULATION AND EVALUATION OF \\ FAST DISINTEGRATING TABLETS (FDT) ATORVASTATIN
}

\author{
Dilal Adlin Fadil ${ }^{1}$, Taofik Rusdiana ${ }^{1}$, Muchtaridi $^{2}$ \\ ${ }^{1}$ Departmen Farmasetik dan Teknologi Farmasi Fakultas Farmasi Universitas Padjadjaran \\ ${ }^{2}$ Departmen Analisis Farmasi dan Kimia Medisinal Fakultas Farmasi Universitas Padjadjaran \\ Email: kang.dilal@gmail.com
}

\begin{abstract}
ABSTRAK
Atorvastatin merupakan salah satu zat aktif penurun kolesterol darah golongan statin atau inhibitor HMG-CoA reductase. Atorvastatin memiliki karaktersitik biofarmasetik kelarutan dalam air yang buruk tetapi permeabilitas dalam membran usus yang tinggi (BCS kelas II), sehingga untuk memperbaiki bioavailabilitasnya dapat diupayakan dengan cara memperbaiki tingkat kelarutannya dalam air. Penelitian ini bertujuan untuk mengetahui pengaruh kompleksasi inklusi atorvastatin dengan $\beta$-siklodekstrin terhadap kelarutan dan disolusinya serta terhadap proses formulasi sediaan Fast Disintegrating Tablets (FDT). Kompleks inklusi dibuat dengan cara kneading method dengan perbandingan molar atorvastatin dengan $\beta$-siklodkestrin; 1:1, 1:2, dan 1:3. Studi ketetapan kesetimbangan kompleks didapat 502,087 $\mathrm{M}^{-1}$. Hasil uji disolusi dalam medium buffer fosfat $\mathrm{pH}$ 6,8 menunjukkan peningkatan laju disolusi atorvastatin dalam kompleks inklusi atorvastatin- $\beta$-siklodkestrin (KIAS) masing-masing sekitar 5,76\% (1:1); 8,89\% (1:2); dan 7,73\% (1:3). Hasil karakterisasi KIAS dengan metode X-ray difraction (X-RD), spektroskopi inframerah, dan differential scaning calorimetry (DSC) menunjukkan adanya pembentukan kompleks inklusi. Formulasi FDT dibuat dengan menggunakan metode kempa langsung terhadap 6 formula ( 3 formula menggunakan KIAS dan 3 formula tanpa KIAS), superdisintegrat yang digunakan adalah Kyron T 314 dengan variasi penggunaannya masing-masing sebanyak 2 , 4, dan $6 \%$ dan variasi kekerasan tablet sebesar 4 dan 6 N. Hasil evaluasi FDT menunjukan bahwa FDT dengan KIAS lebih baik dibandingkan dengan FDT tanpa KIAS. Hasil uji disolusi FDT dalam medium buffer fosfat $\mathrm{pH}$ 6,8 diketahui terjadi peningkatan laju disolusi atorvastatin dalam FDT KIAS. Dengan demikian, dapat disimpulkan bahwa kompleksasi inklusi atorvastatin dengan $\beta$-siklodkestrin dapat meningkatkan laju disolusi atorvastatin secara signifikan.
\end{abstract}

Kata kunci: Atorvastatin, $\beta$-siklodkestrin, Kompleks Inklusi, FDT 


\begin{abstract}
Atorvastatin is one of the active substances blood cholesterol-lowering statins or the inhibitor of HMG-CoA reductase. Atorvastatin has karaktersitik biofarmasetik solubility in water but the permeability in the intestinal membrane which height (BCS class II), so to fix bioavailabilitasnya can be attempted by way of fixing the level of solubility in water. This research aims to know the influence of inclusion complexation with $\beta$-siklodekstrin atorvastatin against the solubility and disolusinya as well as process formulation preparation Fast Disintegrating Tablets (FDT). Inclusion complex made by way of kneading method by comparison molar atorvastatin with $\beta$-siklodkestrin; 1:1, 1:2, and 1:3. The study of the equilibrium complex Ordinance obtained 502.087 M-1. Test results better dissolution takes in the medium of $\mathrm{pH} 6.8$ phosphate buffer showed increased rates of atorvastatin in complex inclusion better dissolution takes atorvastatin- $\beta$ siklodkestrin (KIAS) each around 5.76\% (1:1); 8.89\% (1:2) and 7.73\% (1:3). The results of the characterization of KIAS with method of $x$-ray difraction $(X-R D)$, infrared spectroscopy, and differential scaning calorimetry (DSC) showed a complex formation of inclusion. FDT formulations created by using the method of continuous direct 6 formula (formula 3 and formula 3 KIAS uses without KIAS), the superdisintegrat used is Kyron T 314 with variations of each usage by as much as 2, 4, and 6\% of the variation of hardness tablet of 4 and $6 n$. evaluation results indicate that FDT FDT with KIAS is better compared to the FDT without KIAS. Test results in the FDT better dissolution takes buffer phosphate pH 6.8 note an increase in the rate of atorvastatin in FDT better dissolution takes KIAS. Thus, it can be concluded that the inclusion complexation with $\beta$-siklodkestrin atorvastatin may increase the rate of atorvastatin significantly better dissolution takes
\end{abstract}

Keywords: Atorvastatin, $\beta$-siklodkestrin, Inclusion Complex, FDT

\title{
PENDAHULUAN
}

Atorvastatin merupakan salah satu zat aktif penurun kolesterol darah golongan statin atau inhibitor HMG-CoA reduktase, yaitu senyawa yang dapat menghambat konversi enzim HMG-CoA reduktase menjadi mevalonat sehingga menghambat pembentukan kolesterol endogen (Nielsen, 2014). Atorvastatin memiliki keunggulan dalam efektifitasannya sebagai antikolesterol dibandingkan dengan obat golongan statin lainnya (Lablanche, 2001).

Atorvastatin masuk pada kategori BCS II, cepat terdegradasi pada $\mathrm{pH}$ fisiologis (Ajmera et al., 2012). Kelarutan atorvastatin $\left(6.30 \times 10^{-4} \mathrm{~g} / \mathrm{L}\right)$ menyebabkan atorvastatin mengalami first fast effect, sehingga pemberian oral atorvastatin menjadi kurang efektif. Atorvastatin selain itu memiliki rasa yang 
sangat pahit. Berdasarkan hal tersebut maka atorvastatin perlu diformulasikan dengan tepat agar dapat maksimal memberikan efek terapi dan memiliki nilai akseptabilitas yang tinggi. Upaya peningkatan kelarutan zat sukar larut air, bisa dilakukan diantaranya dengan metode pembentukan kompleks inklusi dengan $\beta$ siklodekstrin (KIAS) (Loftsson et al., 2007). Pembentukan KIAS diketahui dapat meningkatkan kelarutan dan disolusi obat yang memiliki kelarutan rendah dalam air (Fernandes, 2002). Beberapa penelitian telah dilakukan yaitu diantaranya pada peningkatan kelarutan rouvastatin (Akbari et al., 2011), simvastatin, pravastatin, celecoxibusing (Swati, 2004), warfarin (Zingone et al., 2005). Dan telah adanya peningkatan kelarutan pada pembentukan kompleks atorvastatin dengan $\beta$ siklodekstrin (Ajmera et al., 2012). Pada kompleks inklusi, molekul obat sebagai molekul tamu terperangkap di dalam rongga siklodekstrin yang bersifat hidrofobik. Bagian luar siklodekstrin bersifat hidrofilik sehingga mudah larut dalam media air (Loftsson et al., 2014). $\beta$-siklodekstrin terdiri dari tujuh unit glukopiranosa yang dihubungkan oleh ikatan alfa-1,4-glikosida. $\beta$-siklodekstrin memiliki kelarutan dalam air yang rendah $(1,85 \mathrm{~g} / 100 \mathrm{~mL})$. $\beta$-siklodekstrin tidak toksik bila diberikan secara oral terutama digunakan dalam formulasi tablet dan kapsul (Patel et al., 2008).

Penelitian ini bertujuan untuk mengetahui pengaruh KIAS terhadap peningkatan laju disolusi atorvastatin. Atorvastatin akan dibentuk kompleks dengan $\beta$-siklodekstrin sehingga rasa pahit atorvastatin dapat tertutupi, memberikan rasa nyaman di mulut dan dapat diterima oleh pasien. Penelian terdahulu telah membuat kompleks inklusi atorvastatin dengan $\beta$-siklodekstrin (KIAS) dengan cara kneeding method, yaitu membuat campuran fisik atorvastatin dengan $\beta$-siklodekstrin yang dibasahi dengan sejumlah volume minimum campuran air dan etanol dengan perbandingan molar 1:1, 1:2, 1:3 sampai terbentuk masa seperti pasta, kemudian dikeringkan dalam oven vakum pada suhu $45^{\circ} \mathrm{C}$ sampai berat konstan, lalu diayak dengan pengayak nomor 60 (Ajmeera et al., 2012). Karakteristik kompleks dilihat dengan menggunakan $X$-ray diffractometry (XRD) dan Differential scanning calorimetry (DSC) (Sanjay et al., 2014). 


\section{METODE PENELITIAN}

Bahan aktif penelitian berupa atorvastatin didapat dari PT. Kimia Farma Plan Bandung Tbk, Bandung, Indonesia dan $\beta$-siklodkestrin diperoleh dari PT. Sanbe Farma, Bandung, Indonesia.

Jalannya Penelitian

1. Uji pendahuluan

Uji pendahuluan dilakukan dengan cara uji organoleptik meliputi pemerian, panjang gelombang maksimum $(\lambda)$, dan keasaman $(\mathrm{pH})$. Penentuan panjang gelombang, ditentukan dengan menimbang 10,23 $\mathrm{mg}$ atorvastatin menggunakan pelarut etanol kemudian dianalisis dengan menggunakan spektrofotometri pada rentang panjang gelombang 200-250 nm. Panjang gelombang yang memiliki serapan paling besar, merupakan panjang gelombang maksimum atorvastatin (Ajmera et al., 2012).

2. Studi kelarutan dan uji disolusi

Studi kelarutan atorvastatin dilakukan pada pelarut etanol dan juga pada larutan buffer fosfat $\mathrm{pH}$ 6,8. Studi kelarutan dan profil disolusi dilakukan terhadap atorvastatin tanpa kompleksasi dan terhadap kompleks atorvastatin (Ajmera et al., 2012).

3. Kelarutan atorvastatin dalam etanol

Sebanyak 10,23 mg atorvastatin dilarutkan dengan etanol $100 \mathrm{~mL}$, kemudian dimasukan ke dalam orbital shaker pada suhu $25^{\circ} \mathrm{C}$, dengan kecepatan 100 rpm. Pengambilan dilakukan setiap 4 jam selama 24 jam. Diambil sebanyak $10 \mathrm{~mL}$ pada setiap kali pengambilan, diencerkan $10 \mathrm{~mL}$ bagian yg diambil dengan $100 \mathrm{~mL}$ etanol, sampel kemudian diukur dengan menggunakan spektrofotometri pada panjang gelombang maksimum $246 \mathrm{~nm}$ (Sanjay et al., 2014).

4. Kelarutan kompleks inklusi atorvastatin dengan $\beta$-siklodekstrin dalam etanol

Dilakukan prosedur yang sama dengan penentuan kelarutan atorvastatin dalam etanol. Prosedur ini berlaku untuk semua perbandingan molar kompleks atorvastatin- $\beta$-siklodekstrin 1:1, 1:2 dan 1:3 (Sanjay et al., 2014).

5. Kelarutan atorvastatin dalam larutan buffer posfat $\mathrm{pH} 6,8$

Dilakukan prosedur yang sama dengan penentuan kelarutan atorvastatin dalam etanol. 
6. Kelarutan kompleks inklusi atorvastatin dengan $\beta$-siklodekstrin dalam larutan buffer posfat $\mathrm{pH} 6,8$

Dilakukan prosedur yang sama dengan penentuan kelarutan atorvastatin dalam etanol. Prosedur ini berlaku untuk semua perbandingan molar kompleks atorvastatin- $\beta$-siklodekstrin 1:1, 1:2 dan 1:3 (Sanjay et al., 2014).

7. Disolusi atorvastatin

Uji disolusi serbuk atorvastatin ditetapkan dengan metode II USP (tipe alat dayung), kecepatan pengadukan 50 putaran per menit. Medium disolusi larutan buffer posfat $\mathrm{pH} 6,8$ sebanyak $900 \mathrm{~mL}$ dengan temperatur $37 \pm 0,5^{\circ} \mathrm{C}$. Larutan sampel diambil pada interval waktu 5, 15, 20, 25, 30 dan 60 menit sebanyak 5 $\mathrm{mL}$, kemudian segera diganti dengan medium disolusi sebanyak $5 \mathrm{~mL}$ dengan temperatur yang sama. Larutan sampel disaring menggunakan millipore 0,45 $\mu \mathrm{m}$. Hasil penyaringan ini kemudian diukur serapannya pada $\lambda=246 \mathrm{~nm}$ (Ajmera et al., 2012).

8. Disolusi kompleks inklusi atorvastatin dengan $\beta$-siklodekstrin

Dilakukan prosedur yang sama dengan penentuan disolusi atorvastatin dalam etanol.

9. Penentuan tetapan kesetimbangan kompleks inklusi atorvastatin dengan $\beta$ siklodekstrin

Penentuan tetapan kesetimbangan kompleks dilakukan dengan mencampurkan sebanyak 10,23 mg atorvastatin kedalam larutan $\beta$-siklodekstrin dengan variasi konsentrasi $\beta$-siklodekstrin sebesar 4, 6, 8, 10, 12, 14 dan 16 mM, kemudian dilakukan pengocokan dengan menggunakan rotari shaker thermostated pada suhu $25^{\circ} \mathrm{C}$ pada $150 \mathrm{rpm}$ selama 4 hari atau sampai mencapai kadar kesetimbangan. Diukur setiap larutan kompleks dengan menggunakan spktrofotometri UV pada $\lambda=246 \mathrm{~nm}$. Penentuan konstanta kesetimbangan kompleks atorvastatin- $\beta$-siklodekstrin ditentukan dengan memplot konsentrasi atorvastatin dan konsentrasi $\beta$-siklodekstrin, kemudian dicari persamaan garisnya. Konstata kesetimbangannya dihitung menggunakan persamaan : $\mathrm{K} 11=[\mathrm{b}: \mathrm{a}(1-$ b)], dimana "b" adalah slope dan "a" adalah intersep (Ajmera et al., 2012). Tetapan kesetimbangan kompleks inklusi atorvastatin merupakan syarat dan 
indikator keberhasilan suatu inklusi kompleks. Menurut Szejtli (1997) nilai tetapan kompleks yang baik adalah berada antara $100-10.000 \mathrm{M}^{-1}$.

10. Pembuatan kompleks inklusi atorvastatin dengan $\beta$-siklodekstrin

Pembuatan campuran fisik kompleks atorvastatin dengan $\beta$-siklodekstrin dibuat dengan menggunakan kneading method yaitu dengan cara membuat campuran fisik atorvastatin dengan $\beta$-siklodekstrin yang dibasahi dengan sejumlah volume minimum campuran air dan etanol dengan variasi perbandingan molar $1: 1 ; 1: 2$; dan 1:3, sampai terbentuk masa seperti pasta, kemudian dikeringkan dengan menggunakan oven vakum pada suhu $45^{\circ} \mathrm{C}$ sampai berat konstan.

11. Pemurnian dan penetapan kadar

Pemurnian atorvastatin yang terinklusi dalam sistem biner dilakukan dengan cara mencuci sejumlah kompleks dengan etanol untuk menghilangkan atorvastatin bebas kemudian disaring dan residu dikeringkan, kemudian dilarutkan kembali dalam $100 \mathrm{~mL}$ akuades dan diukur serapan yang didapat dengan spektrofotometri UV pada $\lambda=246 \mathrm{~nm}$. Penetapan kadar atorvastatin total dilakukan dengan melarutkan sejumlah kompleks ke dalam 100 mL akuades, kemudian dilakukan pengenceran dan diukur serapan dengan spektrofotometri UV pada $\lambda=246 \mathrm{~nm}$. Persentase atorvastatin yang diinklusi $\beta$-siklodekstrin dalam kompleks, dihitung terhadap atorvastatin total (Ajmera et al., 2012).

12. Karakterisasi kompleks inklusi atorvastatin dengan $\beta$-siklodekstrin

Karakterisasi KIAS dilakukan menggunakan metode spektroskopi inframerah (S-IR), difraktometri sinar-X (XRD), dan differential scanning calorimetry (DSC). Karakterisasi ini dilakukan terhadap atorvastatin, $\beta$ siklodekstrin, dan campuran fisik kompleks inklusi (Akbari, 2011).

\section{a. Differential Scanning Calorimetry (DSC)}

Sebanyak 5-10 mg sampel diletakkan pada crucible alumina instrumen DSC. Analisis termal dilakukan pada rentang temperatur $20-220^{\circ} \mathrm{C}$ dengan laju pemanasan $2^{\circ} \mathrm{C}$ per menit. Analisis termal dengan DSC dapat menunjukkan transisi fase baik endotermik maupun eksotermik. Perbedaan suhu fase transisi seperti titik lebur dapat menunjukkan adanya kompleks inklusi atorvastatin- $\beta$ siklodekstrin (Akbari, 2011). 
b. X-Ray Diffractometry (XRD)

Sebanyak 50-100 mg sampel pada sample holder diletakkan di ruang sampel difraktometer sinar-X. Analisis dilakukan pada rentang sudut difraksi $2 \theta$ $0-50^{\circ}$ dengan step size $0,0170^{\circ}$ menggunakan radiasi $\mathrm{CuK} \alpha(\mathrm{K} \alpha 1=1,54060 \mathrm{~nm}$; $\mathrm{K} \alpha 2=1,54439 \mathrm{~nm}$ ) pada $45 \mathrm{kV}$ dan $40 \mathrm{~mA}$ (Akbari, 2011).

c. Spektroskopi Inframerah

Identifikasi spektrum inframerah dilakukan terhadap atorvastatin, $\beta$ siklodekstrin, dan kompleks inklusi. Metode persiapan sampel menggunakan pelet KBr. Spektrum diukur pada panjang gelombang 4000-400 $\mathrm{cm}^{-1}$. Spektrum yang diperoleh dibandingkan, terutama di daerah sidik jarinya (Akbari, 2011).

13. Pembuatan FDT

Metode yang digunakan dalam pembuatan FDT adalah dengan kempa langsung. Superdisintegrat yang digunakan adalah Kyron T 314 dengan variasi kadar 2, 4 dan $6 \%$.

Tabel I. Perbedaan variasi yang ditetapkan pada setiap Formula FDT

\begin{tabular}{lcccccc}
\hline Jenis Variasi & F1 & F2 & F3 & F4 & F5 & F6 \\
\hline Atorvastatin (Atv) & $\sqrt{ }$ & $\sqrt{ }$ & $\sqrt{ }$ & & & \\
Atv - Bcd & & & & $\sqrt{ }$ & $\sqrt{ }$ & $\sqrt{ }$ \\
Kyron T 314 (2\%) & $\sqrt{ }$ & & & $\sqrt{ }$ & & \\
Kyron T 314 (4\%) & & $\sqrt{ }$ & & & $\sqrt{ }$ & \\
Kyron T 314 (6\%) & & & $\sqrt{ }$ & & & $\sqrt{ }$ \\
\hline Kekerasan Tab 6N & $\sqrt{ }$ & $\sqrt{ }$ & $\sqrt{ }$ & $\sqrt{ }$ & $\sqrt{ }$ & $\sqrt{ }$ \\
\hline
\end{tabular}

Tabel II. Bobot bahan aktif dan bahan pembantu pada setiap formula FDT dengan menggunakan atorvastatin tanpa kompleksasi

\begin{tabular}{|c|c|c|c|c|c|c|}
\hline \multirow{2}{*}{$\begin{array}{l}\text { Nama } \\
\text { Bahan }\end{array}$} & \multicolumn{6}{|c|}{ Bobot (mg) 200 tablet } \\
\hline & F1 & F2 & F3 & $\mathbf{F 4}$ & F5 & F6 \\
\hline Atorvastatin & 2.000 & 2.000 & .000 & - & - & - \\
\hline Atv $-\beta C D$ & - & - & - & 4.000 & 4.000 & 4.000 \\
\hline Kyr & 800 & 1.600 & 2.400 & 80 & 1.600 & 2.400 \\
\hline Avice & 6.000 & 6.000 & 6.000 & 6.000 & 6.000 & 6.000 \\
\hline A & 200 & 200 & 200 & 20 & 200 & 200 \\
\hline & 800 & 800 & 800 & 800 & 800 & 800 \\
\hline Manit & .200 & 29.400 & 28.600 & 28.200 & 27.400 & 26.600 \\
\hline Bobot Total & 40.000 & 40.000 & 40.000 & 4.000 & 4.000 & 40.000 \\
\hline
\end{tabular}


FDT kompleks adalah FDT dengan menggunakan kompleks atorvastatin dengan komposisi molar terbaik. FDT dibuat sebanyak 6 formula. Setiap formula dibedakan dengan variasi kadar Kyron T 314. Bobot tablet ditetapkan sebesar 200 mg. Adapun perbedaan yang ditetapkan pada setiap formula dapat dilihat pada Tabel I dan besaran bobot zat aktif serta bahan pembantu dapat dilihat pada Tabel II.

\section{Evaluasi FDT}

Evaluasi FDT meliputi evaluasi granul sebelum pengempaan dan evaluasi FDT setelah pengempaan tablet (Anonim, 2008).

\section{Evaluasi Granul}

Dilakukan evaluasi terhadap bahan serbuk tablet, meliputi; berat jenis ruah, berat jenis mampat, kecepatan alir dan kompresibilitas (Anonim, 2008).

\section{Evaluasi Tablet FDT}

Dilakukan evaluasi terhadap tablet FDT yang telah dikempa, meliputi: uji keseragaman bobot, uji kekerasan tablet, uji friabilitas, uji waktu hancur, uji waktu pembasahan, uji disolusi.

\section{HASIL DAN PEMBAHASAN}

A. Hasil Pemeriksaan Bahan Baku

Pada pemeriksaan bahan baku, diketahui bahwa atorvastatin memiliki sifat organoleptik sebagaimana pada Tabel III.

Tabel III. Hasil pemeriksaan bahan baku atorvastatin

\begin{tabular}{ccc}
\hline Sifat yang diamati & Pustaka* $^{*}$ & Hasil \\
\hline Pemerian & serbuk putih pucat & serbuk putih pucat \\
Keasaman $(\mathrm{pH})$ & 7,4 & 7,4 \\
Titik leleh $\left({ }^{\circ} \mathrm{C}\right)$ & 145,7 & 145,7 \\
Panjang gelombang $\lambda(\mathrm{nm})$ & 246 & 246 \\
\hline
\end{tabular}

\section{B. Hasil Uji Kelarutan Atorvastatin dan Kompleks Atorvastatin}

Studi kelarutan atorvastatin dilakukan pada pelarut etanol dan juga pada larutan buffer fosfat $\mathrm{pH}$ 6,8. Studi kelarutan atorvastatin untuk mengetahui nilai kelarutan intrinsik atorvastatin dalam pelarut etanol dan larutan buffer fosfat $\mathrm{pH}$ 
6,8, sedangkan studi kelarutan kompleks atorvastatin untuk mengetahui pengaruh kompleksasi atorvastatin dengan $\beta$-siklodekstrin pada kelarutan atorvastatin. Data kelarutan atorvastatin tanpa kompleksasi kelarutan kompleks atorvastatin dapat dilihat pada Tabel IV.

Tabel IV. Hasil uji kelarutan atorvastatin dan kompleks atorvastatin

\begin{tabular}{lcccc}
\hline \multicolumn{1}{c}{ Nama Pelarut } & Atn $(\mathbf{m g} / \mathbf{m L})$ & $\begin{array}{c}\text { Atn:bcd 1:1 } \\
(\mathbf{m g} / \mathbf{m L})\end{array}$ & $\begin{array}{c}\text { Atn:bcd1:2 } \\
(\mathbf{m g} / \mathbf{m L})\end{array}$ & $\begin{array}{c}\text { Atn:bcd 1:3 } \\
(\mathbf{m g} / \mathbf{m L})\end{array}$ \\
\hline $\begin{array}{l}\text { Etanol }\left(25^{\circ} \mathrm{C}\right) \\
\text { Larutan buffer fosfat } \mathrm{pH}\end{array}$ & 0,104 & 0,0936 & 0,1051 & 0,1042 \\
$6,8\left(37^{\circ} \mathrm{C}\right)$ & 1,0283 & 1,0502 & 1,0238 & 1,0687 \\
\hline
\end{tabular}

C. Hasil Uji Disolusi Atorvastatin

Hasil uji disolusi terhadap atorvastatin dapat dilihat pada tabel $\mathbf{V}$.

Tabel V. Hasil disolusi atorvastatin

\begin{tabular}{ccccccc}
\hline $\mathbf{t}$ (menit) & $\begin{array}{c}\text { Serapan } \\
(\mathbf{n m})\end{array}$ & $\begin{array}{c}\mathbf{C} \\
\mathbf{u g} / \mathbf{m L}\end{array}$ & $\mathbf{F K}$ & $\begin{array}{c}\text { FK } \\
\text { Kumul }\end{array}$ & $\begin{array}{c}\mathbf{C} \\
\mathbf{u g} / \mathbf{m L}\end{array}$ & $\begin{array}{c}\text { \% } \\
\text { Disolusi }\end{array}$ \\
\hline 5 & $0,0983 \pm 0,13$ & 2,256 & - & - & 2,256 & 19,85 \\
15 & $0,0991 \pm 0,05$ & 2,276 & 0,0256 & 0,0256 & 2,301 & 20,26 \\
20 & $0,0995 \pm 0,18$ & 2,286 & 0,0276 & 0,0502 & 2,336 & 20,56 \\
25 & $0,0996 \pm 0,26$ & 2,288 & 0,0286 & 0,0788 & 2,366 & 20,83 \\
30 & $0,0997 \pm 0,04$ & 2,290 & 0,0288 & 0,1076 & 2,397 & 21,10 \\
60 & $0,1006 \pm 0,03$ & 2,312 & 0,0290 & 0,1366 & 2,448 & 21,55 \\
\hline
\end{tabular}

Keterangan : C $=$ Konsentrasi, FK = Faktor Koreksi, FK Kumul = Faktor Koreksi Kumulatif

D. Hasil Uji Disolusi Kompleks Atorvastatin

Hasil uji disolusi terhadap kompleks inklusi atorvastatin masing-masing rasio, bisa dilihat pada Tabel V. Adapun perbandingan profil disolusi antara atorvastatin dengan kompleks atorvastatin, dapat dilihat pada Gambar 1. Uji disolusi menunjukkan adanya peningkatan pada profil disolusi terhadap atorvastatin kompleks dibandingkan dengan atorvastatin tanpa kompleks inklusi. Hal ini disebabkan karena adanya interaksi kompleks yang dapat meningkatkan kelarutan atorvastatin. 


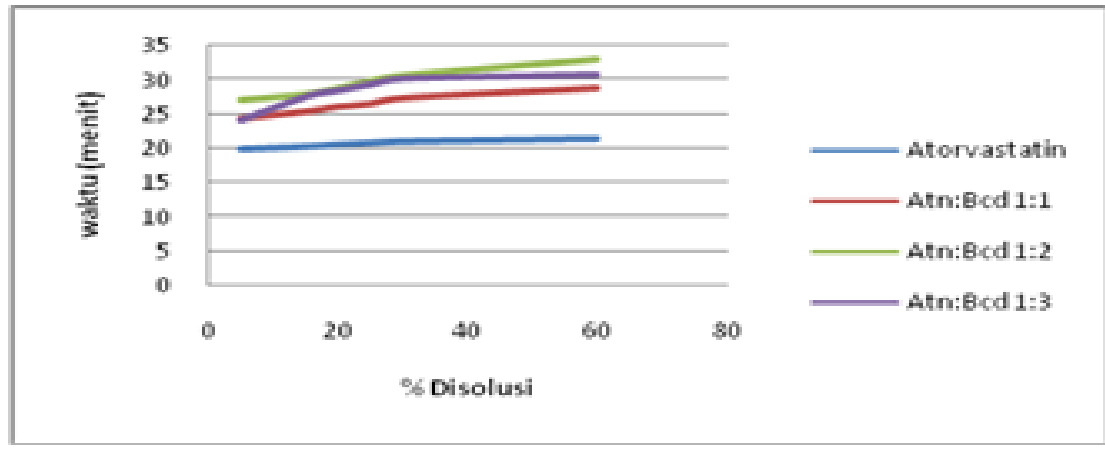

Gambar 1. Perbandingan profil disolusi atorvastatin dengan kompleks atorvastatin

E. Studi Kesetimbangan KIAS

Studi tetapan kesetimbangan kompleks dapat dilihat pada Gambar 2.

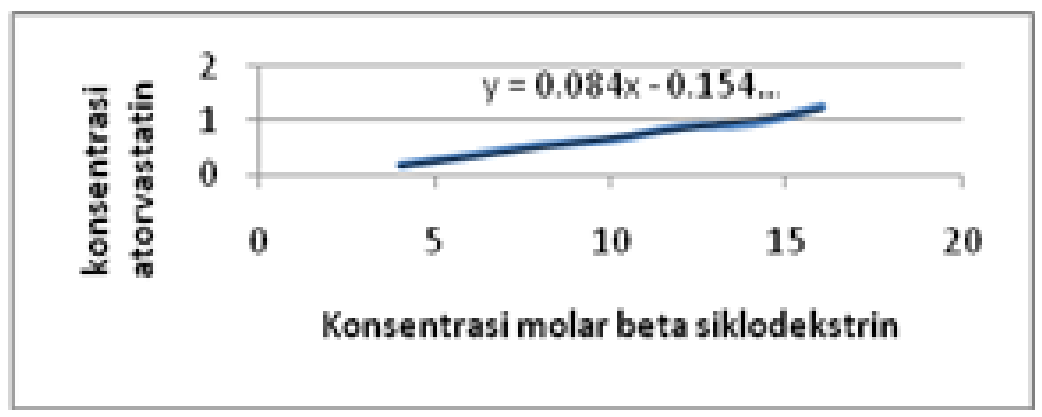

Gambar 2. Tetapan kesetimbangan kompleks

Konstanta kesetimbagan adalah K1.1 = b / (a.(1-b))

$$
\begin{aligned}
& =0,0842 /(0,1547 .(1-0,0842)) \\
& =0,18087 \\
& =502,087 \mathrm{M}^{-1}\left(100-10.000 \mathrm{M}^{-1}\right)
\end{aligned}
$$

Menurut Szejtli (1997) nilai tetapan kompleks yang baik adalah berada antara $100-10.000 \mathrm{M}^{-1}$

F. Hasil Pembuatan Campuran Fisik Kompleks Inklusi Atorvastatin dengan $\beta$ Siklodekstrin

Pembuatan kompleks inklusi ini bertujuan untuk meningkatkan kelarutan atorvastatin. Dari berbagai metode peningkatan kelarutan yang ada, pembentukan kompleks inklusi diketahui merupakan metode baru. Metode ini dipilih karena memiliki beberapa kelebihan, diantaranya penggunaan eksipien berupa 
siklodekstrin yang diketahui nontoksik saat diberikan peroral. Selain itu, penggunaannya telah digunakan luas di dunia farmasi karena availabilitas dan ukuran rongganya yang sesuai untuk banyak obat ketika menginklusi berbagai jenis obat. Pada metode kneading, kompleks inklusi dibuat dengan pembentukan konsistensi slurry (pasta) antara $\beta$-siklodekstrin dengan etanol. Oven vakum pada suhu $45^{\circ} \mathrm{C}$ digunakan karena dapat mengeringkan slurry dalam waktu relatif singkat akibat proses pemanasan pada permukaan dan bagian dalam bahan terjadi pada kecepatan yang sama. Selain itu, oven vacum juga dapat memberikan paparan temperatur yang cukup, sehingga memudahkan pembentukan kompleks inklusi. Pembuatan campuran fisik KIAS dibuat dengan menggunakan kneading method dengan variasi perbandingan molar atorvastatin dengan $\beta$-siklodekstrin $1: 1 ; 1: 2 ;$ dan $1: 3$.

\section{G. Hasil Karakterisasi KIAS dengan DSC}

Termogram DSC atorvastatin memperlihatkan puncak endotermik pada suhu $145,7^{\circ} \mathrm{C}$ yang berhubungan atau ada pada rentang titik leleh atorvastatin sendiri $\left(120-160^{\circ} \mathrm{C}\right)$. Termogram $\beta$-siklodekstrin memperlihatkan puncak endotermik yang lebar yaitu pada rentang suhu $50-130^{\circ} \mathrm{C}$ dan memiliki puncak endotermik pada suhu $78,1^{\circ} \mathrm{C}$. Termogram kompleks inklusi atorvastatin dengan cara kneading methode memperlihatkan adanya interaksi kompleks antara atorvastatin dengan $\beta$-siklodekstrin yang ditandai dengan pengurangan ukuran atau pelebaran puncak endotermik, yang menandakan adanya pembentukan kompleks dimana atorvastatin dienkapsulasi kedalam rongga $\beta$-siklodekstrin. Termogram kompleks menunjukan perubahan puncak endotermik atorvastatin. Pada kompleks dengan rasio 1:1, 1:2, dan 1:3 secara berurutan diketahui memiliki puncak endotermik sebsar 82,$9 ; 89,7$; dan $81,0^{\circ} \mathrm{C}$. Ketiga rasio kompleks tersebut telah terjadi interaksi kompleks inklusi antara atorvastatin dengan $\beta$-siklodekstrin (P. Mura et al., 2001).

Termogram atorvastatin dan kompleks atorvastatin dengan menggunakan DSC, dapat dilihat pada Gambar 3. 


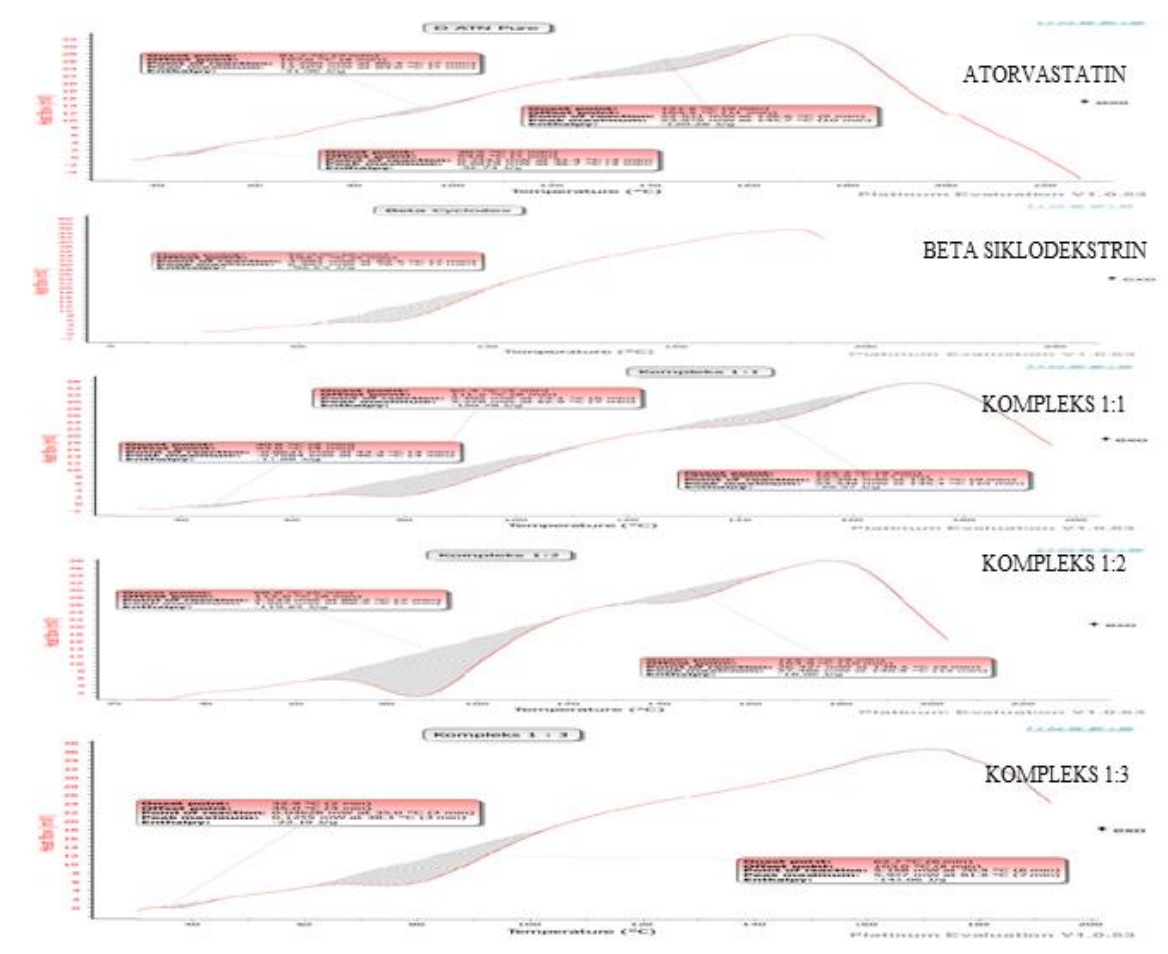

Gambar 3. Hasil karakterisasi DSC

\section{H. Hasil Karakterisasi KIAS dengan XR}

Hasil karakterisasi kompleks inklusi dengan difraktometri sinar-X dapat dilihat pada Gambar 4. Hasil karakterisasi pada kompleks atorvastatin menunjukan kemiripan dengan puncak $\beta$-siklodekstrin. Puncak kristalinitas $\beta$ siklodekstrin terlihat jelas pada $2 \theta=12,66 ; 15,66 ; 16,12 ; 18,24 ; 19,27 ; 21,18$; 22,86; 24,32; 22,57; dan 25,43; sedangkan puncak kompleks inklusi terlihat pada $2 \theta=10,12 ; 11,32 ; 14,76 ; 15,12 ; 17,69 ; 11,38 ; 21,17 ; 19,54 ; 17,27$; dan 22,51 . Adapun puncak atorvastatin terlihat pada $2 \theta=7,42 ; 10,22 ; 15,34 ; 24,32 ; 21,15$; 17,$26 ; 14,45 ; 21,74 ; 28,47$; dan 29,20 . Adapun atorvastatin pada $2 \theta=7,42$ tidak tampak pada spektrum kompleks inklusi. Kecenderungan kemiripan pucak antara $\beta$-siklodekstrin dengan kompleks inklusi, mendukung adanya keberhasilan pembentukan kompleks inklusi (Singh et al., 2012). 

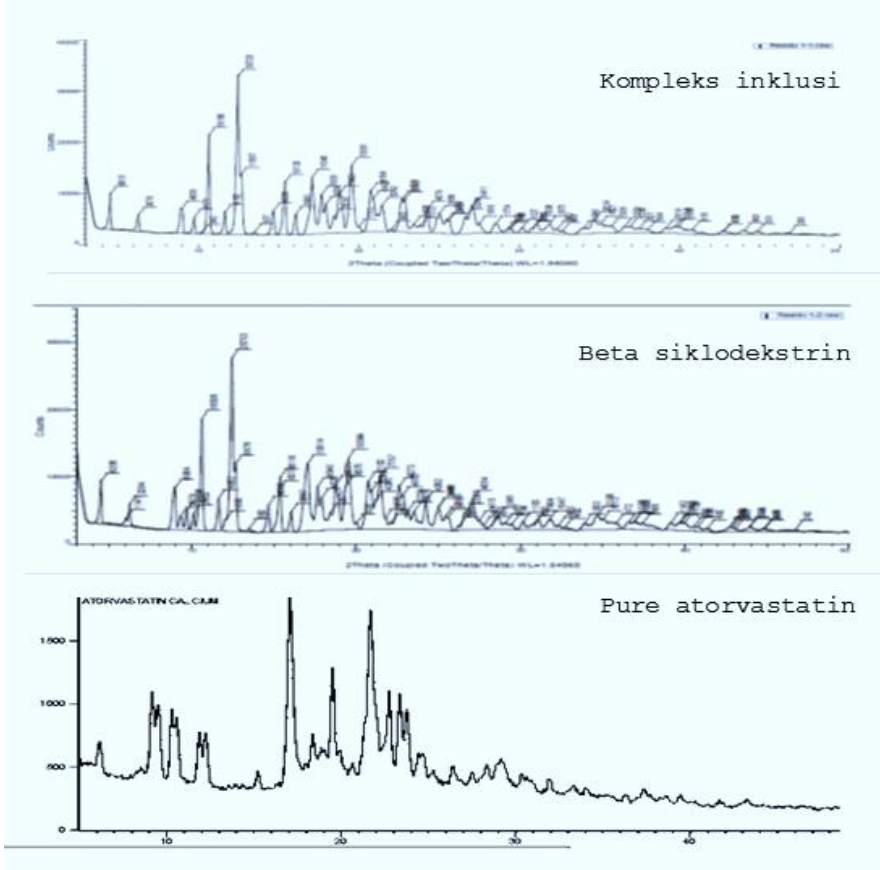

Gambar 4. Hasil karakterisasi dengan XRD

I. Hasil Karakterisasi dengan Spektrofotometri IR

Identifikasi spektrum inframerah (S-IR) dilakukan terhadap atorvastatin, $\beta$ siklodekstrin, dan kompleks atorvastatin-ß-siklodekstrin dapat dilihat pada Gambar 5.
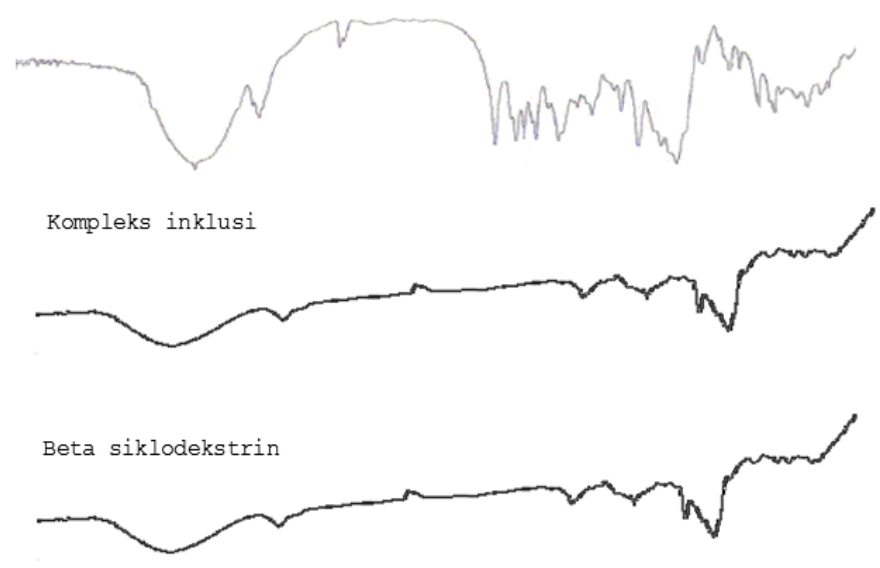

Pure atorvastatin

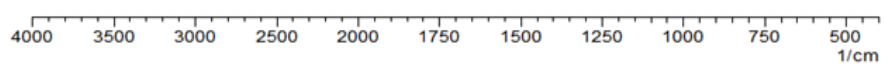

Gambar 5. Hasil karakterisasi dengan S-IR 
Spektrum diukur pada 500-4.000 $\mathrm{cm}^{-1}$. Hasil pengukuran puncak pada spektrum kompleks atorvastatin-ß-siklodekstrin memiliki kemiripan puncak dengan $\beta$-siklodekstrin, hal ini menunjukkan adanya kompleksasi inklusi antara atorvastatin dengan $\beta$-siklodekstrin. Puncak atorvastatin tidak muncul pada spektrum kompleks inklusi atorvastatin- $\beta$-siklodekstrin. Spektrum puncak $ß$ siklodekstrin muncul pada 3.402,20; 2.925,81; dan $1.650 \mathrm{~cm}^{-1}$. Spektrum puncak atorvastatin ada pada $3.365,84 \mathrm{~cm}^{-1}$. Dari hasil ini diketahui bahwa atorvastatin terinklusi di dalam rongga $\beta$-siklodekstrin.

J. Persentase Kompleks Atorvastatin dalam Kompleks Inklusi Padat

Perbandingan rasio prosentase atorvastatin terikat terhadap atorvastatin total dapat dilihat pada Tabel VI.

Tabel VI. Perbandingan rasio kompleks

\begin{tabular}{cccc}
\hline $\begin{array}{c}\text { Rasio } \\
\text { kompleks }\end{array}$ & $\begin{array}{c}\text { Konsentrasi } \\
\text { Atorvastatin Total } \\
(\mathbf{u g} / \mathbf{m L} \mathbf{L}\end{array}$ & $\begin{array}{c}\text { Konsentrasi } \\
\text { Atorvastatin } \\
\text { Terikat }(\mathbf{u g} / \mathbf{m L})\end{array}$ & $\begin{array}{c}\text { Persentase Atorvastatin } \\
\text { Terikat terhadap } \\
\text { Atorvastatin Total }(\%)\end{array}$ \\
\hline $1: 1$ & 23,789 & 22,434 & 94,30 \\
$1: 2$ & 27,134 & 21,650 & 79,78 \\
$1: 3$ & 29,725 & 21,409 & 72,02 \\
\hline
\end{tabular}

\section{K. Hasil Pembuatan FDT}

Tablet FDT dibuat sebanyak 6 formula, terdiri dari 200 tablet dengan bobot tablet $200 \mathrm{mg}$. Setiap tablet mengandung $10 \mathrm{mg}$ dosis atorvastatin. Adapun rincian komposisi tablet dapat dilihat pada Tabel VII.

Tabel VII. Rincian penggunaan komposisi FDT

\begin{tabular}{lcccccc}
\hline \multicolumn{1}{c}{ Bahan FDT } & F1 & F2 & F3 & F4 & F5 & F6 \\
\hline Atorvastatin (Atv) & $\sqrt{ }$ & $\sqrt{ }$ & $\sqrt{ }$ & - & - & - \\
Atv $-\beta$ CD & - & - & - & $\sqrt{ }$ & $\sqrt{ }$ & $\sqrt{ }$ \\
Kyron T 314 (2\%) & $\sqrt{ }$ & - & - & $\sqrt{ }$ & - & - \\
Kyron T 314 (4\%) & - & $\sqrt{ }$ & - & - & $\sqrt{ }$ & - \\
Kyron T 314 (6\%) & - & - & $\sqrt{ }$ & - & - & $\sqrt{ }$ \\
Kekerasan Tab 6N & $\sqrt{ }$ & $\sqrt{ }$ & $\sqrt{ }$ & $\sqrt{ }$ & $\sqrt{ }$ & $\sqrt{ }$ \\
Avicel 102 & $\sqrt{ }$ & $\sqrt{ }$ & $\sqrt{ }$ & $\sqrt{ }$ & $\sqrt{ }$ & $\sqrt{ }$ \\
Aerosil & $\sqrt{ }$ & $\sqrt{ }$ & $\sqrt{ }$ & $\sqrt{ }$ & $\sqrt{ }$ & $\sqrt{ }$ \\
Mg Stearat & $\sqrt{ }$ & $\sqrt{ }$ & $\sqrt{ }$ & $\sqrt{ }$ & $\sqrt{ }$ & $\sqrt{ }$ \\
Manitol & $\sqrt{ }$ & $\sqrt{ }$ & $\sqrt{ }$ & $\sqrt{ }$ & $\sqrt{ }$ & $\sqrt{ }$ \\
\hline
\end{tabular}


L. Hasil Evaluasi FDT

Evaluasi dilakukan pada granul dan FDT atorvastatin. Evaluasi granul dilakukan sebelum pencetakan tablet, sedangkan evaluasi FDT dilakukan setelah pencetakan tablet FDT. Evaluasi FDT dapat dilihat pada Tabel VIII.

Tabel VIII. Hasil evaluasi FDT

\begin{tabular}{cccccc}
\hline Batch & $\begin{array}{c}\text { Keseragaman } \\
\text { Bobot }(\mathbf{m g})\end{array}$ & $\begin{array}{c}\text { Kekerasan } \\
(\mathbf{n m})\end{array}$ & $\begin{array}{c}\text { Friabilitas } \\
(\mathbf{\%})\end{array}$ & $\begin{array}{c}\text { Disintegrasi } \\
(\mathbf{d e t i k})\end{array}$ & $\begin{array}{c}\text { Waktu } \\
\text { Pembasahan } \\
(\mathbf{d e t i k})\end{array}$ \\
\hline F.1 & $200 \pm 0,00$ & 5,97 & 0,750 & 27,5 & 57,00 \\
F.2 & $199,8 \pm 0,01$ & 6,00 & 0,750 & 28,0 & 58,33 \\
F.3 & $199,8 \pm 0,01$ & 5,94 & 0,750 & 27,5 & 58,33 \\
F.4 & $200 \pm 0,01$ & 5,98 & 0,750 & 20,0 & 52,66 \\
F.5 & $199,8 \pm 0,01$ & 6,00 & 0,725 & 21,0 & 51,16 \\
F.6 & $200 \pm 0,00$ & 5,98 & 0,750 & 21,0 & 52,16 \\
\hline
\end{tabular}

M. Hasil Evaluasi Granul

Evaluasi granul meliputi uji berat jenis ruah, uji berat jenis mampat, uji kecepatan alir, dan uji kompresibilitas. Data hasil evaluasi granul, dapat dilihat pada Tabel IX.

Tabel IX. Hasil evaluasi granul

\begin{tabular}{ccccc}
\hline Batch & $\begin{array}{c}\text { Bj Ruah } \\
(\mathbf{g} / \mathbf{m L})\end{array}$ & $\begin{array}{c}\text { Bj Mampat } \\
(\mathbf{g} / \mathbf{m L})\end{array}$ & $\begin{array}{c}\text { Kecepatan Alir } \\
\text { (g/detik) }\end{array}$ & $\begin{array}{c}\text { Kompresibilitas } \\
(\mathbf{\%})\end{array}$ \\
\hline F.1 & 0,424 & 0,47 & 6,46 & 14,89 \\
F.2 & 0,430 & 0,47 & 6,43 & 14,89 \\
F.3 & 0,420 & 0,47 & 6,46 & 14,89 \\
F.4 & 0,423 & 0,51 & 9,26 & 21,56 \\
F.5 & 0,434 & 0,52 & 9,20 & 23,07 \\
F.6 & 0,429 & 0,50 & 9,20 & 18,00 \\
\hline
\end{tabular}

\section{N. Hasil Uji Disolusi FDT}

Hasil perbandingan uji disolusi terhadap FDT atorvastatin dan FDT kompleks atorvastatin dapat dilihat pada Gambar 6. Studi kelarutan atorvastatin tanpa kompleks dan studi kelarutan kompleks inklusi atorvastatin pada suhu $30 \pm 0,5^{\circ} \mathrm{C}$ dibuat untuk mengetahui pengaruhi KIAS. Slope regresi linier dapat dilihat pada perbandingan molar atorvastatin dengan $\beta$-siklodekstrin yang diasumsikan 1:1. Nilai kesetimbangan kompleks yang terbentuk dapat dihitung 
dengan persamaan $\mathrm{k}(1: 1)=$ slope $[\mathrm{SO}$ (1-slope)] dan diperoleh nilai konstanta kesetimbangan mengikuti syarat terbentuknya kompleks yakni pada 502,087 $\mathrm{M}^{-1}$ (100-10.000 $\mathrm{M}^{-1}$ ). Menurut Szejtli (1997) nilai tetapan kompleks yang baik adalah berada antara 100-10.000 $\mathrm{M}^{-1}$, sehingga kompleks inklusi yang terbentuk, cukup stabil.
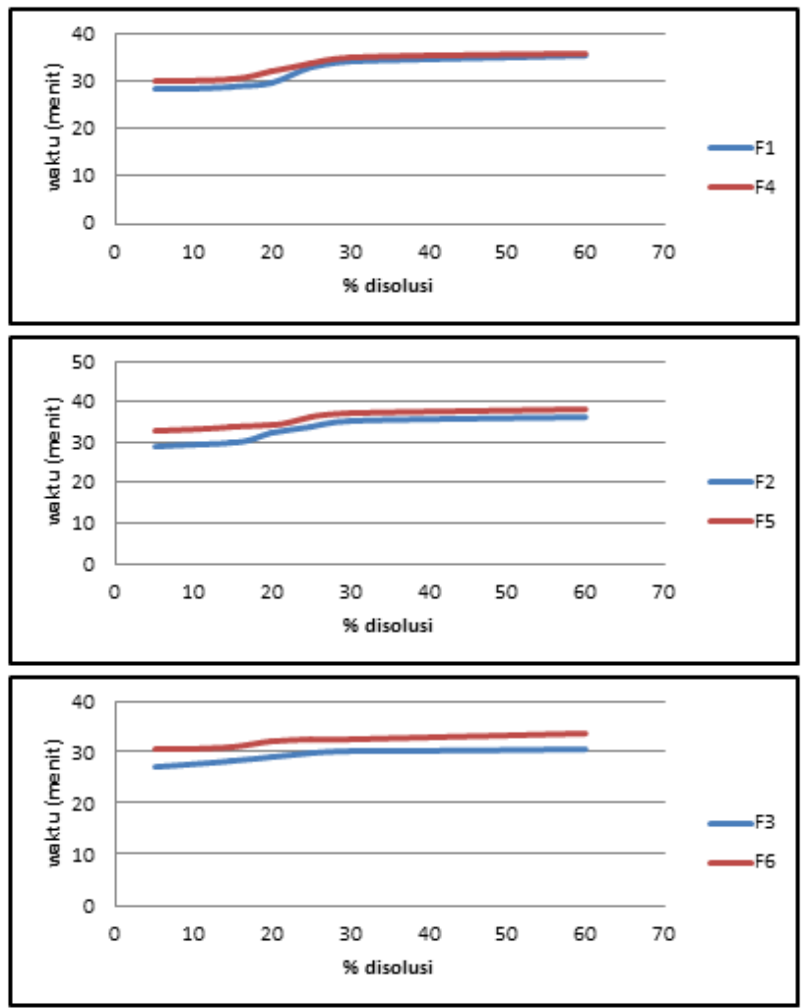

Gambar 6. Grafik perbandingan profil disolusi seluruh formula FDT

Uji disolusi menunjukkan kenaikan angka pada profil disolusi KIAS dibandingkan dengan atorvastatin tanpa kompleksasi. Hal ini disebabkan pengaruh sifat hidrofilik $\beta$-siklodekstrin yang dapat mengurangi tegangan permukaan atorvastatin dengan medium disolusi sehigga laju disolusi menjadi lebih tinggi.

Hasil uji statistik dengan menggunakan student-t, masing-masing rasio kompleks menunjukkan perbedaan yang bermakna dengan tingkat kepercayaan 95\% $(\alpha=0,05)$. Hal ini disebabkan pada rasio kompleks tersebut terdapat proses interaksi antara atorvastatin dan $\beta$-siklodekstrin terjadi dalam keadaan molekular. 
Atorvastatin meningkat kelarutannya setelah dibuat kompleks dengan $\beta$ siklodekstrin. Hasil uji disolusi menunjukkan peningkatan persen disolusi pada setiap rasio kompleks. Pola difraksi sinar-X serbuk pada atorvastatin tanpa kompleks inklusi memberikan puncak difraksi khas. KIAS memberikan pola difraksi menyebar yang menunjukkan bahwa atorvastatin terjerap pada $\beta$ siklodekstrin, yang menyebabkan kelarutan atorvastatin menjadi lebih tinggi dibandingkan bentuk bebas.

Termogram DSC atorvastatin memperlihatkan puncak endotermik pada suhu $145,7^{\circ} \mathrm{C}$. Termogram $\beta$-siklodekstrin memperlihatkan puncak endotermik yang lebar yaitu pada rentang suhu $50-130^{\circ} \mathrm{C}$ dan memiliki puncak endotermik pada suhu $78,1^{\circ} \mathrm{C}$. Termogram kompleks menunjukkan perubahan puncak endotermik atorvastatin. Pada kompleks denga rasio 1:1, 1:2, dan 1:3 secara berurutan diketahui memiliki puncak endotermik sebesar 82,9;89,7; dan $81,0^{\circ} \mathrm{C}$. Adanya interaksi kompleks antara atorvastatin dengan $\beta$-siklodekstrin yang ditandai dengan pengurangan ukuran atau pelebaran puncak endotermik.

Evaluasi granul FDT dan evaluasi tablet FDT menunjukkan formula yang menggunakan KIAS (F4, F5 dan F6) memiliki profil evaluasi yang baik dibandingkan dengan yang tidak menggunakan kompleks atorvastatin. Hasil perbandingan antara atorvastatin dengan kompleks atorvastatin dalam hal profil disolusi menunjukkan adanya kenaikan atau peningkatan, hal tersebut disebabkan adanya pengaruh kompleksasi inklusi atorvastatin dengan $\beta$-siklodekstrin yang dapat meningkatkan kelarutan atorvastatin.

\section{KESIMPULAN}

Hasil disolusi menunjukkan adanya peningkatan laju disolusi atorvastatin dalam kompleks inklusi masing-masing sekitar 5,76\% untuk perbandingan molar $1: 1 ; 8,90 \%$ untuk perbandingan molar $1: 2$; dan 7,73\% untuk perbandingan rasio $1: 3$, dibanding atorvastatin tanpa inklusi. Hasil evaluasi tablet menunjukkan bahwa FDT dengan menggunakan KIAS lebih unggul dibandingkan dengan FDT yang tidak menggunakan kompleks. 


\section{DAFTAR PUSTAKA}

Ajmera, A., Deshpande, S., Patel, P., Patel, K., Solanki, S., Rathod, K., 2012, Reverse phase high performance liquid chromatographic method for simultaneous determination of atorvastatin, ezetimibe and fenofibrate in commercial tablets, Int. J. of Pharm. and Pharmaceutical Sci., 4: 206-209.

Akbari, 2011, Effect of Types of Cyclodextrin on Rosuvastatin Calcium Inclusion Complex, IJP, 2: 1-8.

Fernandes, C.M., Vieira, M.T., and Viega, F.J., 2002, Physicochemical characterization and in vitro dissolution behavior of nicardipinecyclodextrins inclusion compounds, Eur. J. Pharm. Sci., 15: 79-88.

Lablanche, J.M., 2001, Achieving LDL-C target levels: the role of statins, Curr Med Res Opin, 16: 285-295

Loftsson, T., Masson, M., and Brewster, M.E., 2005, Self-Association of Cylodextrin and Cyclodextrin Complexes, J. Pharm. Sci., 93 (9): 1091.

Mura, P; Faucci, M.T; Bettinetti, G.P., 2001, The influence of polyvivylpyrrolidone on naproxen complexation with hydroxypropyl- $\beta$ cyclodextrin. Eur. J. Pharm. Sci., 13: 187-194.

Nielsen, S. and Nordestgaard, B., 2014, Statin use before diabetes diagnosis and risk of microvascular disease: a nationwide nested matched study, Lancet Diabetes Endocrinol, 2: 894-900.

Patel, R., Bhimani, D., Patel, J., and Patel, D., 2008, Solid-state characterization and dissolution properties of ezetimibe-siklodkestrins inclusion complexes, J. Incl. Phenom. Macro, 60: 241-251.

Sanjay, 2014, Formulation and Evaluation of Fixed-Dose Combination of Bilayer Gastroretentive Matrix Tablet Containing Atorvastatin as Fast-Release and Atenolol as Susta ined-Release, Int. J. Biomed, 39 (6): 106.

Swati, R., 2004, Solubility enhancement of celecoxibusing $\beta$-cyclodextrin inclusion complexes, European Journal of Pharmaceutics and Biopharmaceutics, 57: 263-267.

Singh, S.K., Srinivasan, K.K., Singare, D.S., Gowthamarajan, K., and Prakash, D., 2012, Formulation of ternary complexes of glyburide with hydroxypropyl- $\beta$-cyclodextrin and other solubilizing agents and their effect on release behavior of glyburide in aqueous and buffered media at different agitation speeds. Drug Dev Ind Pharm, 38: 1328-1336.

Szejtli, J., 1997, Cyclodextrins in pharmacy, Dordrecht, The Netherlands, Kluwer Academic Publishers.

Zingone, G. and Rubessa, F., 2005, Preformulation study of the inclusion complex warfarin- $\beta$-cyclodextrin, Int J. Pharm, 291 (1-2): 3-10. 